\title{
ReVitaliSASi Lokananta SuRAKarta
}

\author{
Adysty Nugrahani K ${ }^{1}$, Samsudi ${ }^{2}$, Agus Heru Purnomo ${ }^{3}$ \\ Program Studi Arsitektur, Fakultas Teknik, Universitas Sebelas Maret ${ }^{l}$ \\ Email : itsdistiiii@gmail.com \\ Program Studi Arsitektur, Fakultas Teknik, Universitas Sebelas Maret ${ }^{2}$ \\ Program Studi Arsitektur, Fakultas Teknik, Universitas Sebelas Maret ${ }^{3}$
}

\begin{abstract}
Lokananta Surakarta be one proof of the historical progress of Indonesian music industry. However, because the decline since the late 80 s caused by many things, Lokananta gradually dropped prestige resulting in the lonely recording and production activities that culminate in the building neglected and not maintained. In 2014, Lokananta including the 100 buildings and the heritage area of Surakarta, this became the basis for the existence Lokananta preserved and developed. The problem faced is how to revitalize Lokananta that can accommodate all the activities that take place in it by promoting the principle of preservation and revitalization of existing noticed that existed at this time. The purpose of the revitalization Lokananta is generating Lokananta that can accommodate recording activities, recreation, and education. The application of revitalization is done with the protection and maintenance of the main building as well as by adding facilities supporting the activities of musical performances both indoors and outdoors, as well as the infrastructure of leisure activities and education in the form of exhibition venues associated with the development of music and collections owned by Lokananta with regard to rules of preservation and revitalization, and with regard to existing conditions. Revitalization Lokananta Surakarta produce Lokananta able to accommodate the activities of recording, performances, recreation and education and support facilities which can provide added value to Lokananta.
\end{abstract}

Keywords: Lokananta Surakarta, Revitalization, Conservation, Preservation

\section{PENDAHULUAN}

Kehidupan manusia selalu menghasilkan kebudayaan. Salah satu bentuk kebudayaan adalah seni, termasuk juga seni musik. Dahulu mungkin masyarakat hanya bisa menikmati musik lewat pementasan dan festival. Sekarang masyarakat dapat menikmati musik di mana pun dan kapan pun. Hal ini terlihat dari ketertarikan masyarakat terhadap musik, misalnya dengan banyak bermunculan penyanyi atau grup musik dari tahun ke tahun. Di Kota Surakarta pertumbuhan minat masyarakat terhadap musik dapat dilihat dari pertumbuhan jumlah grup musik dan jumlah penyelenggaraan festival musik setiap tahunnya. Penikmatnya pun berasal dari berbagai kalangan dan usia.

Perkembangan teknologi di bidang musik dan audio tidak dipungkiri juga mempengaruhi perkembangan musik. Hal ini memungkinkan industri rekaman musik menghasilkan musik yang lebih murah dengan kualitas yang lebih baik. Studio rekaman yang dapat menghasilkan suara dengan kualitas sangat bagus membutuhkan biaya dan komplektivitas dari peralatan yang digunakan. Sistem rekaman profesional (professional digital studio recording) mempunyai peralatan yang sangat kompleks dengan piranti rack processor, yang terdiri dari compressor, limiter, noise gate, preamp, dan lainnya, piranti mixer yang mempunyai banyak channel, ruang take yang dipenuhi dengan peredam dan sistem akustik yang bagus, hingga kualitas instrumen musik dan mikrofon serta speaker monitor yang berkualitas tinggi. Lokananta terletak di Jalan Ahmad Yani 379 Surakarta. Bangunan studio rekaman Lokananta berdiri di atas lahan 21.500 meter persegi. Bagi Indonesia keberadaan Lokananta 
memberikan bukti kemajuan industri musik. Sebagai tonggak sejarah yang memiliki peranan penting untuk perkembangan musik, sudah seharusnya keberadaan Lokananta diperhatikan, dikembangkan, dijaga, dan dilestarikan aset-aset berharga yang dimilikinya, karena Lokananta menyimpan sejarah yang kelak akan berguna bagi penerus bangsa ini. Pada tahun 2014, Lokananta termasuk pada 100 bangunan dan kawasan cagar budaya yang ditetapkan dalam Surat Keputusan (SK) Kepala Dinas Tata Ruang Kota Surakarta yang merupakan hasil tiga tahun (2011-2013) inventarisasi dan telah dianggap memenuhi kriteria cagar budaya Surakarta sesuai UU No.11/ 2010 tentang Cagar Budaya.

Menurut Piagam Pelestarian Pusaka Indonesia (2003) pelestarian adalah upaya pengelolaan pusaka melalui kegiatan penelitian, perencanaan, perlindungan, pemeliharaan, pemanfaatan, pengawasan, dan/atau pengembangan secara selektif untuk menjaga kesinambungan, keserasian, dan daya dukungnya dalam menjawab dinamika jaman untuk membangun kehidupan bangsa yang lebih berkualitas.

Revitalisasi Lokananta bertujuan meningkatkan fungsi Lokananta sehingga kedepan Lokananta juga mampu mewadahi kegiatan rekaman, pementasan, rekreasi dan edukasi serta fasilitas pendukung yang dapat memberikan nilai tambah pada Lokananta. Dengan menambah fasilitas-fasilitas pendukung kegiatan pementasan musik baik indoor maupun outdoor, serta sarana dan prasarana kegiatan rekreasi dan edukasi berupa tempat pameran yang berhubungan dengan perkembangan musik dan koleksi yang dimiliki Lokananta.

Berdasarkan pada penjelasan di atas maka permasalahannya adalah revitalisasi Lokananta yang dapat mewadahi segala kegiatan yang berlangsung di dalamnya dengan mengedepankan prinsip pelestarian dan revitalisasi serta memperhatikan eksisiting yang ada pada saat ini.

\section{METODE}

\subsection{Strategi Revitalisasi}

Bentuk penanganan dari strategi desain yang akan diterapkan sehubungan dengan konservasi/ pelestarian yaitu pembangunan (pengadaan baru) dan pemeliharaan bangunan cagar budaya (bangunan utama Lokananta)

\subsection{Aksesibilitas antar fungsi kegiatan}

Aksesibilitas antar zona kegiatan menjadi perhatian khuusus pada strategi desain lahan revitalisasi Lokananta.

Strategi ini nantinya akan menjadikan bangunan utama Lokananta sebagai pusat dari bangunan-bangunan baru yang melengkapinya, sehinga aksesibilitas lahan sebagai koneksi visual antar bangunan dan kegiatan dapat terjaga.

\subsection{Lansekap}

Strategi pengolahan lansekap pada lahan Lokananta didasarkan pada fungsi utamanya sebagai fasilitas pendukung bagi kegiatan yang berlangsung di Lokananta.

Pengolahan lansekap selain untuk menentukan penempatan bangunan baru juga akan menghasilkan ruang-ruang sebagai wadah kegiatan publik bagi masyarakat seperti ampiteater untuk pertunjukan outdoor dan fasilitas-fasilitas lain yang berhubungan dengan fungsi obyek revitalisasi seperti lansekap untuk fasilitas kuliner serta lansekap di sekitar bangunan Lokananta sebagai ruang yang mengkomunikasikan antar pengguna dengan fasilitas serta kegiatan yang ada

\subsection{Sistem akustik}

Pengaplikasian teori akustik pada setiap pengambilan keputusan desain yang berkenaan dengan ruang studio maupun ruang terbuka yang membutuhkan penanganan akustik, sehingga setiap kegiatan yang berlangsung tidak akan terganggu dan tidak mengganggu lingkungan sekitarnya

\section{ANALISIS}

\subsection{Analisis Eksisting Lokananta}

Lokananta terletak di Jalan Ahmad Yani 379 Surakarta, dengan luas lahan 21.500 meter persegi. Pada awal mulanya, Lokananta hanya terdiri dari sebuah bangunan utama yang didirikan pada tahun 1956. Kemudian pada tahun 80-an mulailah dibangun beberapa 
bangunan pendukung, seperti bangunan utama Lokananta, mess kepala cabang, studio musik, gudang penyimpanan grafik, mess staff/pegawai, gudang penyimpanan, gudang penyimpanan, pendopo, dan mushala.

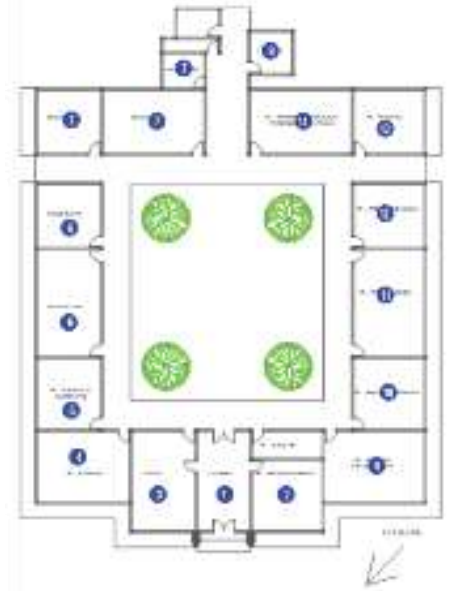

Gambar 1. Denah Bangunan Utama

(Adysty Nugrahani K, 2016)

Pada bangunan utama terdapat beberapa ruangan, yaitu:

a) R. Penerima

b) R. Pemasaran

c) Toko souvenir

d) R. Admin

e) R. Kepala Cabang

f) Museum

g) Gudang

h) Toilet

i) R. Admin Keuangan

j) R. Remastering

k) R. Produksi

1) R. Persediaan

m) R. Panel

n) R. Perpustakaan piringan hitam

Lokananta berada di bawah pengawasan dan pelaksanaan yang dikelola oleh badan usaha milik Negara yaitu Perum PNRI yang dulunya merupakan Departemen Percetakan.

\subsection{Analisis Penerapan Revitalisasi pada Lokananta Surakarta}

Penerapan pada revitalisasi Lokananta dilakukan bangunan utama dengan melakukan beberapa hal, antara lain:

1. Perbaikan-perbaikan pada elemen bangunan yang mengalami kerusakan, dimana kondisi bangunan masih cukup bagus.

2. Gaya interior yang diterapkan pada bangunan utama ini adalah gaya kolonial, karena disesuaikan dengan langgamnya. Meskipun langgam pada bangunan utama merupakan perpaduan antara Langgam Kolonial dan Arsitektur Jawa.

3. Perbaikan ruangan-ruangan pada bangunan utama Lokananta menyesuaikan langgam interior kolonial dan Arsitektur Jawa Tradisional baik furniture, ornamen, maupun desain dekoratifnya, Gaya Kolonial menggunakan material dominan batu bata atau kayu tanpa pelapis serta kayu berpola dengan kekhasan gaya interior tersebut.

\subsection{Analisis Ruang}

Analisis kebutuhan ruang bertujuan untuk mengetahui jenis-jenis ruangan yang dibutuhkan oleh Lokananta yang baru, berdasarkan pada pelaku kegiatan, pola kegiatan, pengelompokkan jenis kegiatan.

Tabel 1. Pengelompokkan Ruang, Kegiatan, dan Fasilitas

\begin{tabular}{|c|c|c|}
\hline Zona & Kegiatan & Fasilitas \\
\hline Penerimaan & $\begin{array}{l}\text { Interprestasi, } \\
\text { parkir, } \\
\text { informasi }\end{array}$ & $\begin{array}{lr}\text { Main } & \text { gate, } \\
\text { parkir, } & \text { pos } \\
\text { jaga, } & \text { pusat } \\
\text { informasi } & \end{array}$ \\
\hline Penunjang & $\begin{array}{l}\text { Ibadah, } \\
\text { metabolisme, } \\
\text { makan, } \\
\text { membeli } \\
\text { souvenir }\end{array}$ & $\begin{array}{l}\text { Mushala, } \\
\text { lavatory, } \\
\text { cafeteria. Toko } \\
\text { ibadah } \\
\text { souvenir }\end{array}$ \\
\hline \multirow[t]{3}{*}{ Inti } & $\begin{array}{l}\text { Rekaman } \\
\text { musik }\end{array}$ & $\begin{array}{ll}\text { R.studio } & \\
\text { rekaman, } & \mathrm{R} . \\
\text { kontrol, } & \mathrm{R} . \\
\text { produksi } & \end{array}$ \\
\hline & $\begin{array}{l}\text { Pementasan } \\
\text { Musik }\end{array}$ & $\begin{array}{ll}\text { Panggung } & \\
\text { terbuka } & \text { dan } \\
\text { panggung } & \\
\text { tertutup } & \end{array}$ \\
\hline & $\begin{array}{l}\text { Pameran } \\
\text { materi koleksi } \\
\text { Lokananta }\end{array}$ & $\begin{array}{l}\text { R.pameran, } \\
\text { R.penyimpanan } \\
\text { piringan hitam }\end{array}$ \\
\hline Pengelolaan & $\begin{array}{l}\text { Koordinasi } \\
\text { dan } \\
\text { administrasi }\end{array}$ & R. pengelola \\
\hline
\end{tabular}

\subsection{Analisis Tapak}

Tapak terletak di Kelurahan Kerten, Kecamatan Laweyan dengan luas lahan 21.500 $\mathrm{m}^{2}$. Batas tapak perencanaan di sebelah barat berbatasan dengan Jalan Ahmad Yani, di 
sebelah utara berbatasan Kantor Kelurahan Kerten, di sebelah timur berbatasan dengan permukiman penduduk, dan di sebelah selatan berbatasan dengan permukiman penduduk.

\subsection{Analisis Pencapaian}

Analisis pencapaian bertujuan untuk menentukan main entrance (ME). Tapak terletak di Jl. Ahmad Yani yang merupakan salah satu jalan utama yang cukup ramai dan mudah untuk diakses baik dengan kendaraan pribadi maupun beberapa kendaraan umum

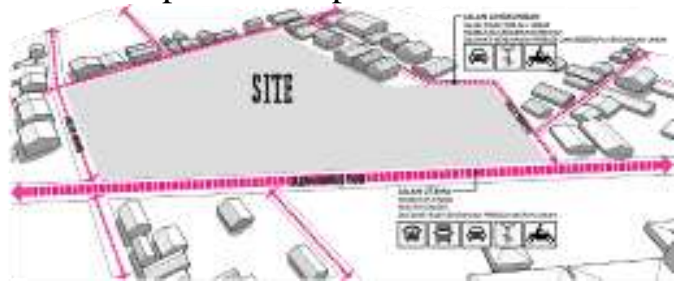

Gambar 2. Analisis Pencapaian (Adysty Nugrahani K, 2016)

Pada eksisting terdapat main entrance yang digunakan untuk jalur masuk dan keluar. Kondisi jalan lingkungan di sekitar tapak (Jl. Merpati dan Jl. Miwis) cukup sepi dengan mobilitas yang tidak terlalu ramai.

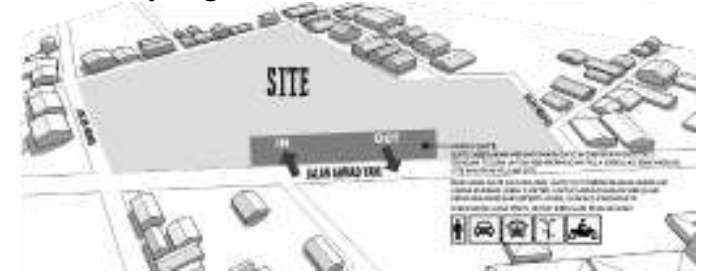

Gambar 3. Respon Desain Pencapaian (Adysty Nugrahani K, 2016)

Main gate diletakkan pada Jalan Ahmad Yani, dengan pemisahan jalur keluar masuk untuk mempermudah pola sirkulasi baik menuju tapak maupun keluar tapak.

\subsection{Analisis Kebisingan}

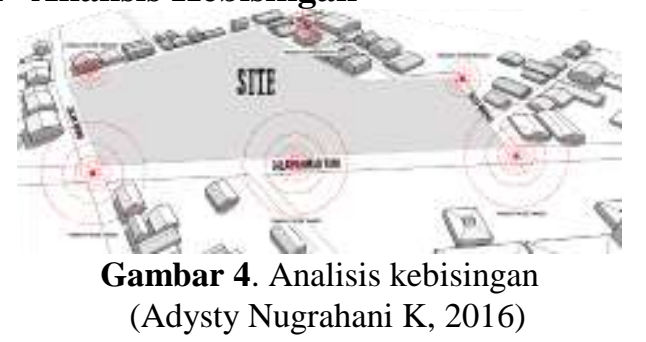

Bising lingkungan berasal dari luar tapak/bangunan, seperti kendaraan bermotor. Potensi kebisingan pada tapak utamanya diperoleh dari kendaraan yang melewati $\mathrm{Jl}$.
Ahmad Yani. Sedangkan kebisingan dengan tingkat yang rendah berada jalan lingkungan yang mengelilingi tapak.

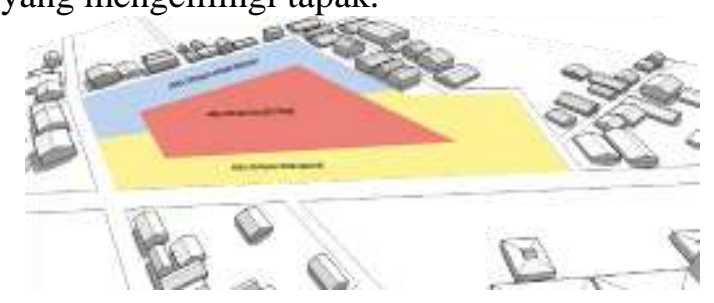

Gambar 5. Respon Desain Kebisingan

(Adysty Nugrahani K, 2016)

Respon desain :

1. Pemberian vegetasi di bagian tapak yang berdekatan dengan Jl. Ahmad Yani bertujuan untuk mereduksi kebisingan dari Jl. Ahmad Yani yang berasal dari kebisingan kendaraan bermotor, sehingga tidak menganggu kegiatan di dalam bangunan.

2. Pemberian vegetasi selain sebagai barrier kebisingan juga untuk elemen estetika.

3. Peletakan ruangan yang mewadahi kegiatan inti menjauhi pusat kebisingan terbesar.

4. Bangunan yang mewadahi kegiatan inti diletakkan agak menjorok ke dalam tapak untuk menjauhi kebisingan

5. Bagian tapak yang berdekatan dengan sumber kebisingan digunakan sebagai zona kegiatan penunjang dan zona kegiatan servis

\subsection{Analisis Pemintakatan (Penzoningan)}

Menurut Perda Kota Surakarta nomor 10 tahun 2013, sistem zonasi terdiri atas :

1. Zona inti (Protection Zone)

2. Zona penyangga (Buffer Zone)

3. Zona pengembangan (Development Zone)

4. Zona penunjang (Supporting Zone)

Dengan adanya peraturan mengenai zonasi pemanfaatan cagar budaya, maka peletakkan kelompok fungsi ruang baru juga harus mempertimbangkan pada peraturan daerah tersebut. Utamanya agar mampu bersinergi dengan bangunan utama, serta tidak mengurangi nilai-nilai pada bangunan cagar budaya.

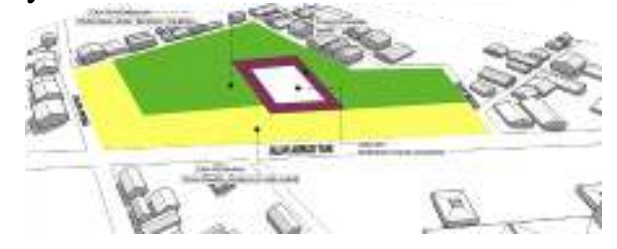


Gambar 6. Pemintakatan

(Adysty Nugrahani K, 2016)

\subsection{Analisis Akustik Studio Rekaman}

Untuk memenuhi kebutuhan akustikal maka perlu diberlakukan langkah-langkah sebagai berikut :

1. Agar tidak terjadi feedback, maka peletakkan speaker tidak diarahkan ke bidang pantul apapun. Arah pemain musik tidak boleh mengarah ke speaker secara langsung

2. Untuk menghindari kebisingan dan kebocoran suara dari luar maka perlu dipasang pintu dan jendela dengan bahan pelapis sekat berupa seal karet atau bahan insulator lain. Kabel-kabel penghubung peralatan dibungkus dengan bahan insulator bunyi, seperti isolasi dan busa, serta jarak sinyal listrik yang ditempuh tidak boleh terlalu panjang.

3. Pemantulan suara dalam ruangan dikurangi dengan memperbanyak material pelapis suara. Semua bagian dinding, langit-langit, dan lantai kecuali kaca dilapisi dengan material penyerap suara.

4. Warna suara yang kering dapat diperoleh dengan pemasangan beberapa material khusus penyerap suara yang diletakkan pada sudut ruangan.

\subsection{Analisis Bentuk dan Tampilan Bangunan}

\subsubsection{Analisis Bentuk Bangunan}

Bentuk dasar yang sesuai untuk digunakan pada massa bangunan baru dari Lokananta yaitu dengan menggunakan kombinasi dari bentuk bujur sangkar ataupun persegi panjang yang merupakan bentuk geometris sederhana dengan penyesuaian dengan bangunan utama, yang nantinya akan diolah lebih lanjut dengan penambahan dan pengurangan bentuk dasar

\subsubsection{Analisis Tampilan Bangunan}

Dasar pertimbangan :

1. mempertimbangkan eksisting bangunan utama Lokananta

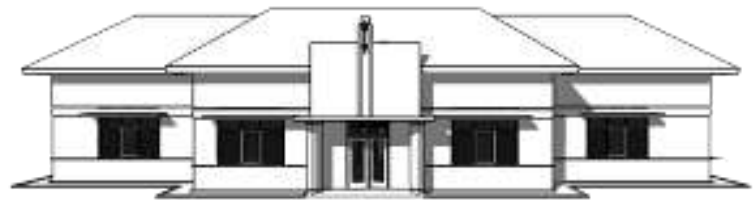

Gambar 7. Tampilan Bangunan Utama

(Adysty Nugrahani K, 2016)

2. tampilan bangunan baru harus dapat memperkuat karakter dari Lokananta

3. tampilan keseluruhan bangunan harus mudah dikenal masyarakat. Oleh karena itu, tampilan bangunan haruslah komunikatif dan atraktif.

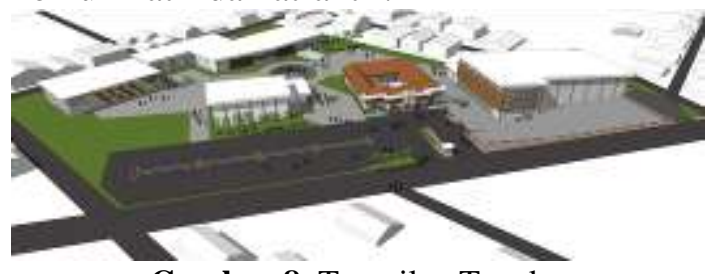

Gambar 8. Tampilan Tapak

(Adysty Nugrahani K, 2016)

Tampilan pada bangunan pendukung sangatlah harus memperhatikan tampilan pada bangunan utama. Elemen-elemen yang terdapat pada bangunan utama juga diterapkan pada beberapa bangunan pendukung lainnya.

\subsection{Analisis Lansekap}

Lansekap yang direncanakan pada, yaitu lansekap yang dapat mengakomodasi pejalan kaki dan juga dapat merespon iklim sekitar bangunan.

Pengolahan lansekap bagi pejalan kaki dapat menggunakan perkerasan, sebagai penanda jalan. Sedangkan pengolahan lansekap yang dapat merespon iklim di sekitar tapak menggunakan vegetasi-vegetasi.

Pemanfaatan olah lansekap pada ruang terbuka di area bangunan, dapat menghadirkan tamantaman sebagai tempat rekreasi ataupun berkumpul bagi pengunjung.

Vegetasi peneduh pada revitalisasi Lokananta yang direncanakan ditanam pada area-area taman yang merupakan tempat bersosialisasi pengunjung, di sekitar panggung terbuka dan tempat parkir. Sedangkan untuk vegetasi penutup, rumput akan ditanam pada area-area taman yang direncanakan.

Pemanfaatan hard landscape ini salah satunya sebagai area sirkulasi pengunjung. Perkerasan aspal pada bagian area parkir, sedangkan paving digunakan pada area lain yang berupa area sirkulasi. Paving dipilih karena dapat menyerap air lebih banyak dibandingkan dengan aspal maupun beton. 


\section{KESIMPULAN (KONSEP DESAIN)}

Dari hasil analisis serta hasil korelasi dari beberapa data di atas, maka diperoleh hasil berupa:

Nama : Lokananta Surakarta

Lokasi : Jl. Ahmad Yani

Luas Lahan $\quad: 21.500 \mathrm{~m}^{2}$

Luas Bangunan : $7.180 \mathrm{~m}^{2}$

Konsep revitalisasi yang diterapkan pada tapak dan bangunan, antara lain :

1. Pembangunan (pengadaan baru)

Pengembangan dengan dilakukan dengan mengadakan fasilitas baru, seperti studio musik, panggung terbuka, dan fasilitas pendukung lainnya sehingga mampu mewadahi kebutuhan saat ini. Setiap desain baru yang dihadirkan di dalam tapak harus memperhatikan desain eksisting yang ada, dengan cara :

a. Rencana tapak dirancang dengan mengikuti zonasi pelestarian sesuai dengan peraturan daerah Kota Solo mengenai cagar budaya.

b. Bangunan lama dijadikan sebagai orientasi ataupun sumber daya desain, sebagai titik acuan, titik ikat, ataupun point of interest.

c. Bentuk massa mengangkat kembali atau reproduksi gaya/style, citra/image, dan ciri/karakter bangunan utama Lokananta yang menjadi objek pelestarian.

2. Peningkatan kualitas dan kuantitas

a. Merupakan usaha untuk memenuhi kebutuhan akan suatu fasilitas baru yang representatif bagi pengunjung dan kepentingan lain yang dapat dijadikan pendukung dan penguat keberadaan Lokananta.

b. Mempertahankan bangunan studio rekaman dengan melakukan beberapa perbaikan untuk meningkatkan kualitas fungsi ruangnya.

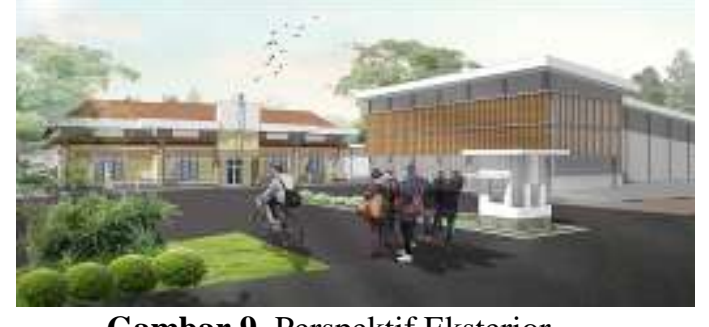

Gambar 9. Perspektif Eksterior

(Adysty Nugrahani K, 2016)

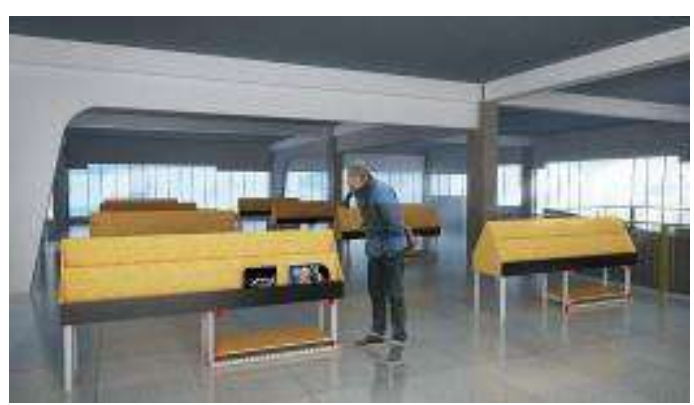

Gambar 10. Interior R. Koleksi

(Adysty Nugrahani K, 2016)

3. Pemeliharaan

Dalam pemeliharaan ini merupakan usaha untuk pemeliharaan sekaligus perbaikan terhadap bangunan konservatif (Lokananta) agar dapat berfungsi sebagaimana kebutuhan.

\section{REFERENSI}

Hapsari, Inertia Indi dan Petrus N. Indradjati. 2015. Strategi Revitalisasi Kawasan Jembatan Merah Surabaya. Jurnal Perencanaan Wilayah dan Kota A.SAPPK V4N2: 1 - 12

Martokusumo, Widjaja. 2006. Revitalisasi dan Rancang Kota: Beberapa Catatan dan Konsep Penataan Kawasan Kota Berkelanjutan. Jurnal Perencanaan Wilayah dan Kota Vol. 17/No.3: 31 46

Pemerintah Kota Surakarta. 2013. Perda Kota Surakarta Nomor 10 Tahun 2013 Tentang Pelestarian Cagar Budaya 